\title{
小型冷凍を用いたヘリウム液化機/再凝縮装置
}

\author{
吉田 茂* ${ }^{*}+\dagger$
}

\section{Helium Liquefier/Recondensation Unit with Cryocoolers}

\author{
Shigeru YOSHIDA ${ }^{* 1, \dagger}$
}

Synopsis: This is a review of compact liquefaction/recondensation equipment with cryocoolers, namely, GM-coolers and pulse tube cryocoolers. The improvement of liquefaction performance is remarkable since the advent of the 4-K pulse tube cryocooler. This article describes a brief history about 4-K cryocoolers and their liquefaction performance. Additionally, commercialized helium gas liquefaction/recondensation systems with cryocoolers are introduced and those specifications are shown.

Keywords: GM cryocooler, pulse tube cryocooler, helium liquefaction/recondensation system

(Some figures in this article may appear in color only in the electronic version)

\section{1. はじめに}

2019 年には再び世界的なへリウム危機が訪れ, 日本物理 学会が中心となり，「ヘリウム危機に臨んでの緊急声明」1) が宣言されたことは記憶に新しいところである。今回のへ リウム危機は生産設備の故障や輸送における問題とは違っ て，本質的な問題である。これまで日本はへリウムの多く を米国からの輸入に依存してきたが，米国のへリウムガス 備蓄方針の転換により，日本への輸出量がかなり制限を受 けた事情に端を発している。

さて，先の緊急声明では，以下の 3 点が主張されている。

1. 日本では，希少で貴重な資源であるへリウムを極力リ

サイクルして使用すべきである。

2. 研究機関のヘリウムユーザー, 関連企業, 政府は協力 してへリウムリサイクルを推進するための環境整備を 行い，研究・企業活動を通してリサイクルに努めるべ きである。

3. 将来のヘリウム危機に備えて備蓄施設の整備が望まし い。

これらの主張を考えると, 液体へリウムのリサイクルに はへリウム液化装置が必要であるし，備蓄には密度の大き い液体へリウムが有利となる。このため, 各地の大型へリ ウム液化機を利用して, 回収ヘリウムガスの再液化や備蓄

Received December 6, 2020

*1 九州大学

干819-0395 福岡県福岡市西区元岡 744

Kyushu University, 744 Motooka, Nishi-ku, Fukuoka 819-0395, Japan

$\dagger$ E-mail: yoshida.shigeru.779@m.kyushu-u.ac.jp DOI: $10.2221 /$ jesj.56.135
用液化ヘリウムの生産が叫ばれている。但し，大型へリウ ム液化機を利用するには, ヘリウムが使用される場所での ヘリウムガス回収設備や，液化センター（液化機設置施設） への輸送が必要となる。そこでヘリウム回収設備が無く, 液化センターから離れた地域における液体へリウムの少量 消費ユーザーには，小型冷凍機を利用したコンパクトな液 化機（再凝縮器）の使用が便利といえる。

今回のヘリウム危機では, 実際液体へリウムの小規模消 費ユーザー（小ロユーザー）では液体へリウムが入手困難 な状況にあった。彼らにはへリウム回収設備や大型の液化 機を据え付けることは非現実的であり，小型冷凍機を利用 した液化機／再凝縮器は非常に有効である。小型冷凍機を 用いたヘリウム液化能力は $4 \mathrm{~K}$ パルスチューブ冷凍機の登 場以来著しい進歩を遂げている。これは液化されるへリウ ムガスの予冷熱交換に蓄冷管を活用した事によるが，この 技術を GM 冷凍機にも応用し，4K-GM 冷凍機によるへリ ウム液化効率も大きく向上した。

ここでは, $4 \mathrm{~K}$ 小型冷凍機出現の歴史と, その後の小型 冷凍機搭載型ヘリウム液化機の進歩を簡潔に振り返る。ま た，現在市販されている代表的な小型冷凍機搭載型へリウ ム液化機／再凝縮装置を紹介寸る。

\section{2. 冷凍機の進歩}

\section{1 GM-JT 冷凍機}

今では 4K-GM 冷凍機や $4 \mathrm{~K}$-パルス冷凍機が市場で容易 に手に入るようになったが，これらは比較的新しい機器で あり，1990 年代に入ってからのことである。それ以前で は, GM 冷凍機に別途 JT（ジュール・トムソン）回路を組 み合わせなければ， $4 \mathrm{~K}$ に到達できなかった。当時はこの 


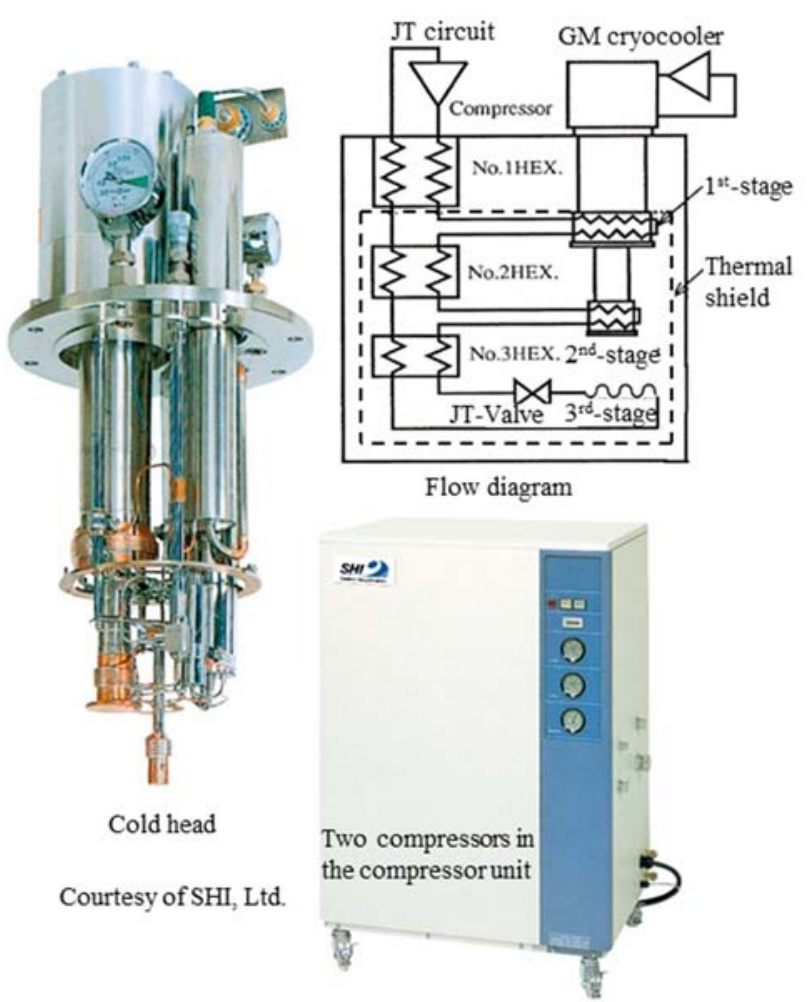

Fig. 1 GM-JT cryocooler.

GM-JT 冷凍機を用いて, ヘリウムガスの液化, 又は再凝 縮を行っていた。まず，代表的な GM-JT 冷凍機 ${ }^{2)}$ を Fig. 1 に示す。これは住友重機械社製の冷凍機で元々はダイキン 工業社で開発されたものである。GM 冷凍機は 2 段式で, 2 段目の蓄冷材には鉛の粒が使用されていた。当時冷凍能 力で 3 種類のタイプがあり, その冷凍能力は $4.3 \mathrm{~K}$ で 1 ～ 5 W であった（Table 1）。一般的な GM-JT 冷凍機の課題とし ては，JT 回路の不純物による閉塞があり，連続運転の信 頼性に多少の難があった。また，JT 弁での熱振動による 侵入熱の予期せぬ増大に悩まされた記憶がある。一方で, 初期の $4 \mathrm{~K}$ 小型冷凍機に比べて冷凍能力の大きな機種があ り，4K 冷凍能力選定の幅の大きなことが利点であった。

Fig. 1 のフロー図から解るように，3 段目ステージ (JT 回路，4 K ステージ） は GM 冷凍機から独立しているので, 3 段目ステージの配置には自由度がある。この自由度を生 かして 3 段目ステージをクライオスタットの中心部まで引 き込んだ例を Fig. 2 に示す ${ }^{3)}$ ささらに Fig. 3 は, SQUID デ バイス用に $4 \mathrm{~K}$ ステージを $\mathrm{GM}$ 冷凍機本体から $1 \mathrm{~m}$ 以上離 した例である ${ }^{4)}$

\section{$2.24 K-G M$ 冷凍機の出現}

世界で初めて GM 冷凍機単体で $4 \mathrm{~K}$ に到達したのは, 1980 年代末であった。当時, 三菱電機のグループが最終 段の蓄冷材に磁性材料を用いた 3 段の GM 冷凍機を製作し た。この GM 冷凍機が世界で最初に文献 5) に現れる 4KGM 冷凍機であると記憶している。Table 2 に当該冷凍機 のへリウム液化能力と各段における温度を記す。 3 段目の
Table 1 GM-JT cryocooler specifications.

\begin{tabular}{cccc}
\hline Model Number & CG304C & CG308C & CG310C \\
\hline 3rd-stage capacity (W) & $1.0 / 1.2$ & $3.0 / 3.5$ & $4.2 / 5.0$ \\
@ $4.3 \mathrm{~K}(50 / 60 \mathrm{~Hz})$ & & & \\
$\begin{array}{c}\text { Power consumption (kW) } \\
50 / 60 \mathrm{~Hz}\end{array}$ & $4.5 / 5.4$ & $5.1 / 6.4$ & $5.1 / 6.4$ \\
\hline
\end{tabular}

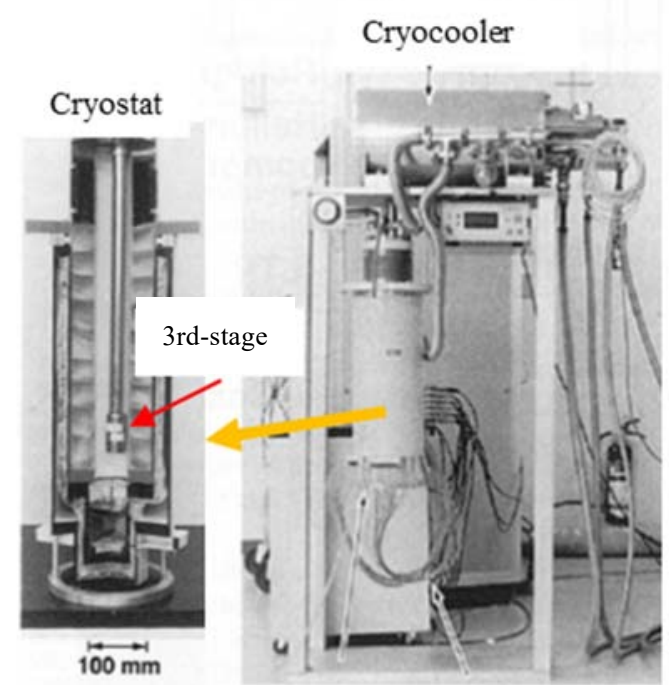

Fig. 2 GM-JT cryocooler for a Josephson computer experiment system.

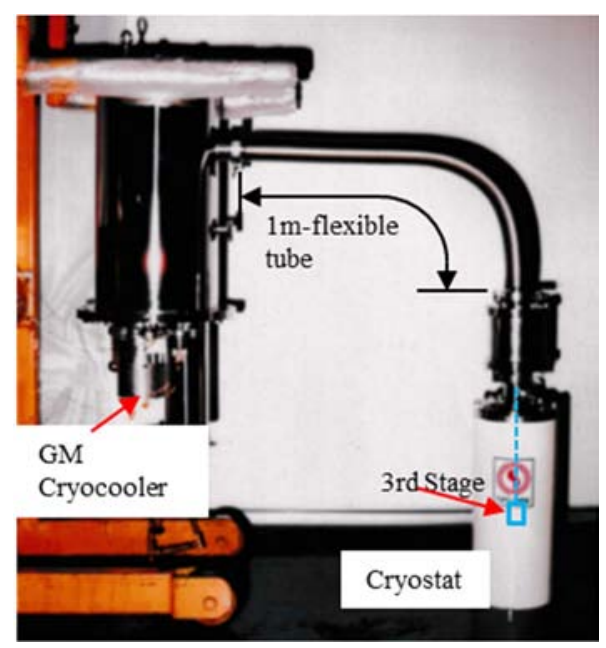

Fig. 3 GM-JT cooler with a 1-m flexible tube.

冷凍能力は $20 \mathrm{~mW} 94.2 \mathrm{~K}$ であり, 液化能力は僅か $10 \mathrm{cc} / \mathrm{hr}$ であった。また, Table 3 に各段に用いられた蓄冷材の種 類を記す。

その後, GM 冷凍機が実用的なへリウム液化装置として 発展するのは，東芝と東工大のグループにより形状を粒径 $300 \mu \mathrm{m}$ の球形に揃えた $\mathrm{Er}_{3} \mathrm{Ni}$ の蓄冷材 ${ }^{6}$ ) が開発されたこと による。この蓄冷材が広く GM 冷凍機の蓄冷材として普及 した理由は, 磁性蓄冷材の形状（球形）及びその直径をコ ントロールできたことである。これにより磁性蓄冷材の蓄 
Table 2 Operation data of the first liquefier with a GM cooler.

\begin{tabular}{ccccc}
\hline $\begin{array}{c}\text { Liquefaction } \\
\text { rate }\end{array}$ & $\begin{array}{c}\text { Cooling power } \\
\text { at 3rd-stage } \\
(4.2 \mathrm{~K})\end{array}$ & $\begin{array}{c}\text { 1st-satge } \\
\text { temperature }\end{array}$ & $\begin{array}{c}\text { 2nd-stage } \\
\text { temperature }\end{array}$ & $\begin{array}{c}\text { Compressor } \\
\text { power }\end{array}$ \\
\hline $10 \mathrm{cc} / \mathrm{hr}$ & $20 \mathrm{~mW}$ & $40 \mathrm{~K}$ & $11 \mathrm{~K}$ & $2.5 \mathrm{~kW}$ \\
\hline
\end{tabular}

Table 3 Regenerator materials in the first liquefier with a GM cooler.

\begin{aligned} & \hline 1st Phosphor bronze (150 mesh, $220 \mathrm{~g}) \\ &$ 2nd Lead shot $(\phi 0.3-0.5 \mathrm{~mm}, 16 \mathrm{~g}) \\ &$ 3rd GdErRh compound $\left(\mathrm{GdRh}+\mathrm{Gd}_{0.5} \mathrm{Er}_{0.5} \mathrm{Rh}\right) \\ &$\hline\end{aligned}

Table 4 The first helium liquefier with a two-stage GM cooler.

\begin{tabular}{ccccc}
\hline $\begin{array}{c}\text { Liquefaction } \\
\text { rate }\end{array}$ & $\begin{array}{c}\text { Cooling } \\
\text { power } \\
(4.2 \mathrm{~K})\end{array}$ & $\begin{array}{c}\text { 1st-satge } \\
\text { temperature }\end{array}$ & $\begin{array}{c}\text { 2nd } \\
\text { regenerator } \\
\text { material }\end{array}$ & $\begin{array}{c}\text { Compressor } \\
\text { power } \\
\text { consumption }\end{array}$ \\
\hline $50 \mathrm{cc} / \mathrm{hr}$ & $0.28 \mathrm{~W}$ & $30 \mathrm{~K}$ & $\begin{array}{c}\mathrm{Er} 3 \mathrm{Ni} \\
\phi 0.2-\phi 0.4\end{array}$ & $3.1-3.4 \mathrm{~kW}$ \\
\hline
\end{tabular}

冷性能と信頼性が大きく向上することとなった。更に，東 芝グループはこの蓄冷材（ $\mathrm{Er}_{3} \mathrm{Ni} ， \phi 0.2-\phi 0.4,295 \mathrm{~g} ）$ を 2 段 目蓄冷器に充填し，世界で最初に 2 段 GM 冷凍機によるへ リウム液化に成功した ${ }^{7)}$ 。Table 4 にこの時の GM 冷凍機の 運転状況を示す。

\subsection{K-パルスチューブ冷凍機の出現}

一方, GM 冷凍に遅れること数年で，パルスチューブ冷 凍機も $4 \mathrm{~K}$ に到達した。最初に $4 \mathrm{~K}$ に到達したのは日本大 学の松原チームであった ${ }^{8)}$ 。彼らは 3 段のパルスチューブ 冷凍機を製作し， 3 段目の蓄冷管に鉛と $\mathrm{Er}_{3} \mathrm{Ni}$ を充填した。 この冷凍機の性能特性を Table 5 に示す。彼らが $4 \mathrm{~K}$ に到 達するに当たり, 彼らの第一の功績は 2 段パルスチューブ 冷凍機の形状改良にある。この改良の過程を模式図にて Fig. 4 に示す。これまで， 2 段目のパルスチューブの温端 は 1 段目の冷却ステージへ熱的に接続されていたが， 2 段 目パルスチューブの温端を室温へと延長した。これにより, 2 段目パルスチューブのバッファーオリフィスにて生じる 熱を直接外気に放出できるようになり， 1 段目ステージの 熱負荷が減少し，その結果 2 段目ステージの到達温度を低 下させることに成功した。この技術を 3 段パルスチューブ 冷凍機にも応用した。この改良技術は現在市販の 2 段パル スチューブ冷凍機の基本構造となっている。

日大グループの 3 段パルスチューブ冷凍機の冷凍能力は 0.119 W@4.9 Kであったが，その後, Giessen大のグループ

Table 5 Operation data of the three-stage pulse tube cooler.

\begin{tabular}{cccc}
\hline \hline $\begin{array}{c}\text { Cooling power } \\
\text { at } 4.9 \mathrm{~K}\end{array}$ & $\begin{array}{c}\text { 1st-satge } \\
\text { temperature }\end{array}$ & $\begin{array}{c}\text { 2nd-stage } \\
\text { temperature }\end{array}$ & $\begin{array}{c}\text { 3rd-stage } \\
\text { temperature }\end{array}$ \\
\hline $0.119 \mathrm{~W}$ & $85 \mathrm{~K}$ & $47 \mathrm{~K}$ & $3.6 \mathrm{~K}$ \\
\hline $\begin{array}{c}\text { 1st regenerator } \\
\text { material }\end{array}$ & $\begin{array}{c}\text { 2nd regenerator } \\
\text { material }\end{array}$ & $\begin{array}{c}\text { 3rd regenerator } \\
\text { material }\end{array}$ & \\
\hline Bronze mesh \#250 & Lead $\phi 0.3$ & $\begin{array}{c}\text { Lead } \phi 0.3+\mathrm{Er}_{3} \mathrm{Ni} \\
\end{array}$ & \\
\hline
\end{tabular}

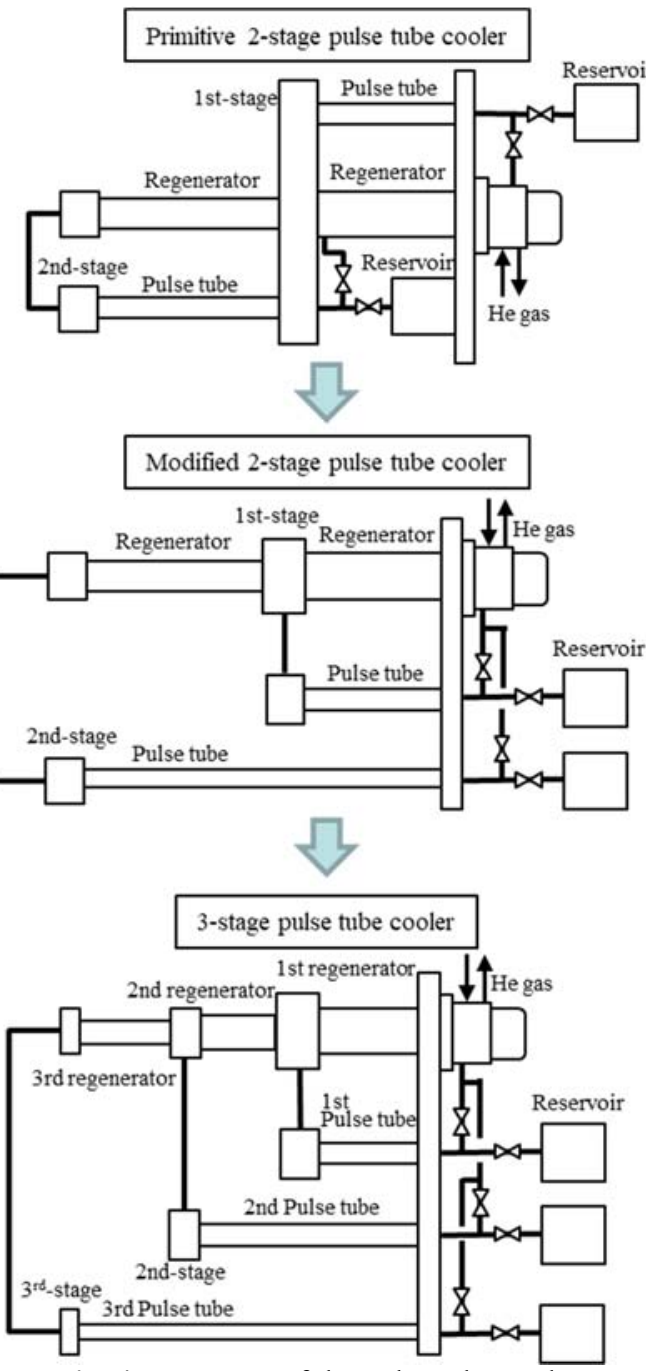

Fig. 4 Progress of the pulse tube cooler.

が $0.37 \mathrm{~W} @ 4.2 \mathrm{~K}$ の 2 段パルスチューブ冷凍機 9) を開発し た。この冷凍機をべースにヘリウム液化装置を製作し，液 化実験を実施した。

\section{3. ヘリウム液化機/再凝縮器}

3.1 GM 冷凍機搭載従来型ヘリウム液化機とパルス チューブ冷凍機搭載改良型ヘリウム液化機

$\mathrm{GM}$ 冷凍機がパルスチューブ冷凍機よりも先に $4 \mathrm{~K}$ に到 達したので，まず GM 冷凍機を用いたへリウム液化機 （GM 冷凍機付きへリウム液化機）が開発された。典型的 な液化装置の模式図を Fig. 5 a)に示す。ここではこのタイ プを従来型, 又は隔離型と呼ぶとする。このタイプは室温 のヘリウムガスを冷凍機が収納されたチャンバーに導入し， 1 段目ステージ（約 $50 \mathrm{~K}$ ）にて予冷を行い，2 段目ステー ジで液化をおこなう方式である。ただし，導入されたへリ ウムガスは, 冷却ステージのみと熱交換を行い, 最終的に 2 段ステージで液化が行われる。これは, GM 冷凍機では シリンダー部位, 特にディスプレーサー部位（蓄冷材収納 部）が外部からの熱擾乱によりその温度勾配が崩れると, 


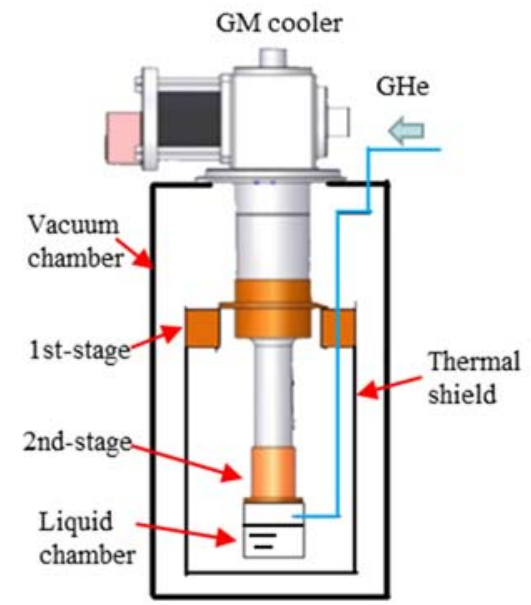

a) Conventional type (Isolated type)

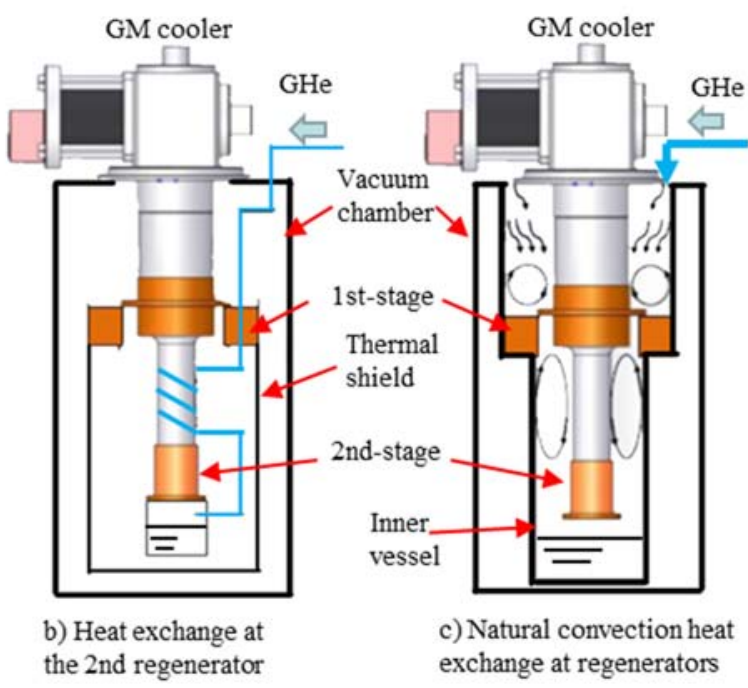

Fig. 5 Helium liquefier with a GM cooler.

冷却ステージへ影響し，冷却ステージ温度が下がらなくな るという懸念から泠凍機シリンダー内の温度勾配を崩さぬ ように冷却ステージ間のシリンダー部（ディスプレーサー

部）を外部と断熱することが常であったことによる。

ところが，先の Giessen 大のグループは，開発した 0.37 $\mathrm{W} @ 4.2 \mathrm{~K}$ パルスチューブ冷凍機を用いて液化実験 ${ }^{10)}$ した ところ同等冷凍能力を持つ GM 冷凍機搭載へリウム液化機 の約 3 倍の液化能力を得た。Fig. 6 に液化実験装置の模式 図を示す。このように，パルスチューブ冷凍機の 2 段目蓄 冷管にスパイラルチューブを巻き付け導入ヘリウムガスと の熱交換器を形成した改良型液化機により大きな液化能力 を得ることとなった。則ち，蓄冷管が有効な冷凍能力を持 つ事実が判明した。そこで，パルスチューブ冷凍機搭載液 化機では，この事実が判明すると積極的に蓄冷管をへリウ ムガスの予冷器として利用した。Cryomech 社のグループ は蓄冷管を予冷器として用いない従来型液化機に比して約 4 倍の液化能力を持つパルスチューブ冷凍機搭載ヘリウム 液化機の開発に成功した ${ }^{11)}$ 。用いたパルスチューブ冷凍機

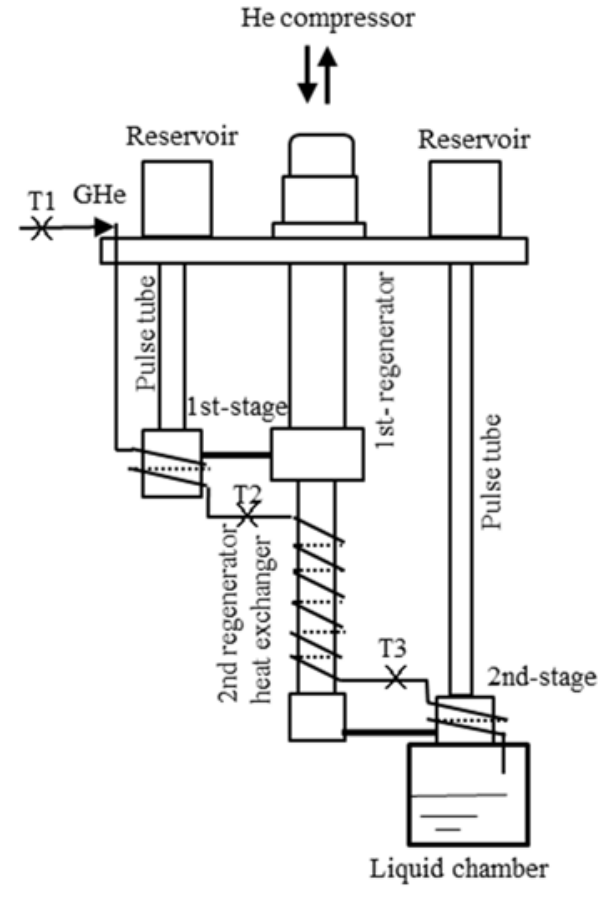

Fig. 6 Pulse tube cooler helium liquefier with a second regenerator heat exchanger.

Table 6 Effects of an additional second regenerator heat exchanger for the pulse tube cooler helium liquefier.

\begin{tabular}{cll}
\hline & \multicolumn{2}{l}{ Improved model $^{* 1}{\text { Isolated } \text { model }^{* 2}}^{*}$} \\
\hline Temperature T1 & $298 \mathrm{~K}$ & $298 \mathrm{~K}$ \\
Temperature T2 & $37.5 \mathrm{~K}$ & $37.5 \mathrm{~K}$ \\
Temperature T3 & $5.7 \mathrm{k}$ & $37.5 \mathrm{~K}$ \\
2nd-stage cooling pow er & $0.635 \mathrm{watt}$ & $1.01 \mathrm{watt}$ \\
Liquefaction rate at $4.2 \mathrm{~K}$ & $14.1 \mathrm{~L} / \mathrm{d}$ & $3.5 \mathrm{~L} / \mathrm{d}$ \\
\hline
\end{tabular}

Remarks: * 1 with second regenerator heat exchanger,

*2 without second regenerator heat exchanger

の機種は PT41012)であり, $4.2 \mathrm{~K}$ で $1 \mathrm{~W}$ の冷凍能力を持つ 冷凍機である。

Table 6 に Cryomech 社の改良型液化機と従来型液化機の 運転温度と液化能力等の比較を示す。ともに導入された室 温のヘリウムガスは 1 段目冷却ステージで $37.5 \mathrm{~K}$ まで冷却 されている。その後, 従来型は 2 段目蓄冷管とへリウムガ スは非接触であり，2段目の冷凍能力は $1 \mathrm{~W}$ を維持してい る。一方, 改良型では導入ヘリウムガスが 2 段目蓄冷管と 積極的な熱交換を行っている。その結果，2 段目冷却ス テージの冷凍能力は $0.635 \mathrm{~W}$ に減少するが, 導入へリウム ガスは 2 段目ステージの直前で $5.7 \mathrm{~K}$ まで予冷されている ことが判る。この結果, 液化量は改良型で 14.1 リッター/ 日，従来型は 3.5 リッター/日という結果となった。

\section{2 GM 冷凍機を用いた改良型ヘリウム液化機/再凝縮器} 上述のパルスチューブ冷凍機と同様な改良を GM 冷凍機 に施すことがミュンヘン工科大学で試みられた（Fig. 5 b)。 
彼らは 2 段目シリンダーにスパイラルチューブを巻き付け ることにより熱交換器を形成し, 導入へリウムガスの予冷 を行った。その結果 GM 冷凍機（SHI 社製 RDK-415，1.5 $\mathrm{W} @ 4.2 \mathrm{~K}) 1$ 台で, 13 リッター/日の液化量を得た ${ }^{13)}$ 。 GM 冷凍機の場合，蓄泠材は上下動する容器（ディスプレー サールピストン）に詰められており，且つディスプレー サー/ピストンは冷凍機本体のシリンダー内に収納されて いる。このため, 蓄冷管が剥き出しのパルスチューブ冷凍 機と比べると，蓄冷材と導入へリウムガスの熱交換性能が 多少劣ることは免れない。このため, 当初は, GM 冷凍機 の 2 段目シリンダーを予泠器に利用することは難しいので はないかと思われていたが，この実験により当初の危惧を 見事に払しょくすることとなった。また，IUAC (Inter University Accelerator Center) のチームは冷凍機シリンダー と導入ヘリウムガスの熱交換に自然対流を積極的に活用し た結果，上述の GM 冷凍機同機種（RDK-415）を用いて,

17.4 リッター/日の液化量を得ている ${ }^{14)}$ 。著者の計算によ れば, RDK-415 を搭載した従来機種の液化量は 5.3 リッ ター/日であるので, 液化機として極めて大きな進歩であ るといえる。

このようにいくつかの実験により, GM 冷凍機もパルス チューブ冷凍機と比肩できる液化能力を持つことが示され た。現在 GM 冷凍機とパルスチューブ冷凍機といった小型 冷凍機によるへリウム液化機の主流は蓄冷材と導入ヘリウ ムガスとの熱交換性能を備えたタイプとなっている。

\section{3 市販のヘリウム液化機/再凝縮器}

種々のメーカーが小型冷凍機を搭載した液化機/再凝縮装 置を市販している。液化量は小さいもので 1 リッター/日か ら最大 200 リッター/日まであり, 代表的なメーカーのライ ンナップを Table 7 に示す。この表には液化機に利用されて いる小型冷凍機の型式と冷凍機の消費電力（カタログ值, 一部推定值）を記載している。この一覧表は液体へリウム 小ロユーザーによる液化機の機種選定の一助になると思う。 以下に，各メーカーの機種の特長を記す。

Cryomech 社はパルスチューブ冷凍機のトップランナーで あり，いち早くパルスチューブ冷凍機の持つ高効率へリウム 液化能力に着目し，パルスチューブ冷凍機搭載のヘリウム液 化機を市販したメーカーである。さらに，Cryomech社は4.2 $\mathrm{K}$ で冷凍能力 $2 \mathrm{~W}$ のパルスチューブ冷凍機（PT420）15）を持 つことが強みであり，PT420を 3 台搭載した液化能力 80 リッター/日という液化能力最大級の小型ヘリウム液化機を 製品化している ${ }^{16)}$ 。

Quantum Technology 社（以下 QT 社）は，自社ブランド の $\mathrm{GM}$ 冷凍機 $\mathrm{QCH} 4 \mathrm{KDHH}^{17}$ をを用いたへリウム液化機を市 販している。QCH4KDHH は $50 \mathrm{~Hz}$ 運転で $1.8 \mathrm{~W} @ 4.2 \mathrm{~K}, 60$ $\mathrm{Hz}$ 運転で $2 \mathrm{~W} @ 4.2 \mathrm{~K}$ の冷凍機である。QCH4KDHHを 1 台 搭載した液化機は 20 リッター/日の液化能力であるが，冷 凍機を 1 台増設するごとに 20 リッター/日の液化量が増加
Table 7 Marketed helium liquefaction/recondensation units.

\begin{tabular}{|c|c|c|c|c|c|}
\hline \multirow[t]{2}{*}{ Maker } & \multirow[t]{2}{*}{ Model No. } & \multirow{2}{*}{$\begin{array}{l}\text { Liquefaction } \\
\text { rate } \\
(\mathrm{L} / \mathrm{d})\end{array}$} & \multirow{2}{*}{$\begin{array}{c}\text { Cryocooler } \\
\text { model } \\
\text { nominal } \\
\text { cooling power } \\
\text { @ } 4.2 \mathrm{~K}\end{array}$} & \multicolumn{2}{|c|}{$\begin{array}{c}\text { Power } \\
\text { consumption } \\
(\mathrm{kW})\end{array}$} \\
\hline & & & & $@ 50 \mathrm{~Hz}$ & $@ 60 \mathrm{~Hz}$ \\
\hline \multirow{5}{*}{ Cryomech } & LHeP15 & 15 & $\begin{array}{l}\text { PT410 } \\
(1 \mathrm{~W})\end{array}$ & 7.9 & 8.4 \\
\hline & LHeP22 & 22 & $\begin{array}{l}\text { PT415 } \\
(1.5 \mathrm{~W})\end{array}$ & 9.2 & 10.7 \\
\hline & LHeP28 & 28 & $\begin{array}{l}\text { PT420 } \\
(2 \mathrm{~W})\end{array}$ & 11.4 & 12.5 \\
\hline & LHeP55 & 55 & $\begin{array}{l}\text { PT420 } \\
(4 \mathrm{~W}) \times 2\end{array}$ & 22.8 & 25.0 \\
\hline & LHeP80 & 80 & $\begin{array}{l}\text { PT } 420 \times 3 \\
(6 \mathrm{~W})\end{array}$ & 34.2 & 37.5 \\
\hline \multirow{4}{*}{$\begin{array}{l}\text { Quantum } \\
\text { technology }\end{array}$} & QL20 & 20 & $\begin{array}{l}\text { QCH4KDHH } \\
(1.8-2 \mathrm{~W})\end{array}$ & 6.5 & 7.8 \\
\hline & QL40 & 40 & $\begin{array}{l}\text { QCH4KDHH } \\
(1.8-2 \mathrm{~W}) \times 2\end{array}$ & 13.0 & 15.6 \\
\hline & QL60 & 60 & $\begin{array}{l}\text { QCH4KDHH } \\
(1.8-2 \mathrm{~W}) \times 3\end{array}$ & 19.5 & 23.4 \\
\hline & QL80 & 80 & $\begin{array}{l}\text { QCH4KDHH } \\
(1.8-2 \mathrm{~W}) \times 4\end{array}$ & 26.0 & 31.2 \\
\hline \multirow{3}{*}{ TNSC } & TRG305PT & 1 & $\begin{array}{l}\text { SRP062B } \\
(0.5 \mathrm{~W})\end{array}$ & 6.5 & 7.5 \\
\hline & TRG330PT & 8 & $\begin{array}{l}\text { SRP082B } \\
(1 \mathrm{~W})\end{array}$ & 7.8 & 8.9 \\
\hline & TRG375DS & 18 & $\begin{array}{l}\text { RDK415D } \\
(1.5 \mathrm{~W} \times 2)\end{array}$ & 13.0 & 15.0 \\
\hline \multirow{2}{*}{$\begin{array}{l}\text { Quantum } \\
\text { design }\end{array}$} & ATL80 & 12 & $\begin{array}{l}\text { RDK408D } \\
\text { (1 watt) }\end{array}$ & 3.8 & 5.4 \\
\hline & ATL160 & 22 & $\begin{array}{l}\text { RDK415D } \\
(1.5 \mathrm{~W})\end{array}$ & 6.5 & 7.5 \\
\hline
\end{tabular}

する製品を提供している。現在の同社のカタログには 10 台 装着した液化量 200 リッター/日までの液化機が掲載され ている ${ }^{18)}$ 。

ここで，ともに液化能力 80 リッター/日の Cryomech 社 LHeP80 と Quantum Technology（QT）社 QL80 を比較してみ ると, 搭載している冷凍機の冷凍能力はほぼ同じ（2 W@4.2 K）であるが，冷凍機の搭載台数は LHeP80 では 3 台に対してQL80は4台となっている。これはパルスチュー ブ冷凍機の方が多少ヘリウム液化能力の高いことが理由で ある。一方, 消費電力を見ると QL80 は 4 台の GM 冷凍機 を搭載しているにも拘わらず，パルスチューブ冷凍機 3 台 搭載の LHe80 より小さい。GM 冷凍機はパルスチューブ冷 凍機より効率が良いことが理由である。また，一般的に冷 凍機 1 台当たりの価格は GM 冷凍機の方がパルスチューブ 冷凍機よりも安価である。 


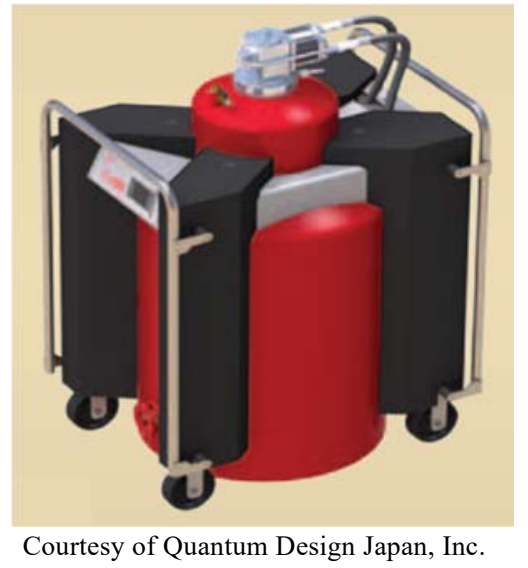

Fig. 7 Helium liquefier ATL 160.

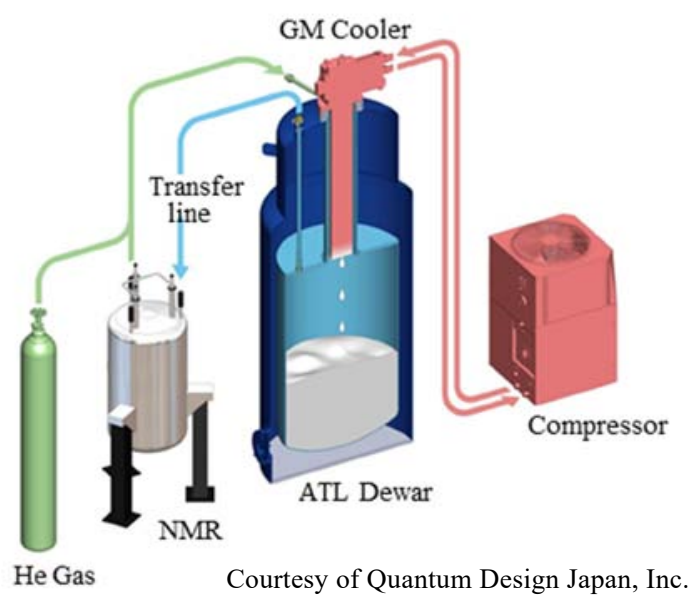

Fig. 8 Typical liquefaction system with ATL 160.

Quantum Design 社は SHI 社の GM 冷凍機を搭載した液化 機 2 種類（ATL80, ATL160）を市販している。Fig. 7 に ATL160 を，Fig. 8 にATL を用いた典型的な液化システムの 代表例を図示する。このシステムでは，外部からのへリウ ムガスと NMR から蒸発したガスを ATL に戻し，ATL 内で 再液化したのち，液体へリウムを NMR にトランスファー するシステムとなっている。必要に応じて, NMR 装置へ卜 ランスファーする際のフラッシュガスを回収するための バッファータンクを設置する例もある。

次に, 大陽日酸社（TNSC）のへリウム再凝縮装置を Fig. 9 に示す。こちらの装置は実験用の液体へリウム容器に断 熱管を差し込むタイプである。容器から蒸発したへリウム ガスを上方の装置本体に取り込み、再凝縮した液体へリウ ムを容器に戻し, 容器からの蒸発損失を防ぐタイプである。 この機種は，1 台の実験装置ごとに 1 台の再凝縮装置が対 応する。搭載する小型冷凍機は GM 冷凍機とパルスチュー ブ冷凍機の両タイプがある。NMR装置では振動の少ないパ ルスチューブ冷凍機が好まれるようであるが, GM 冷凍機 でも NMR 測定に支障がないとの事である。パルスチュー ブ冷凍機は必ず縦置き姿勢で装着しなければならないので,

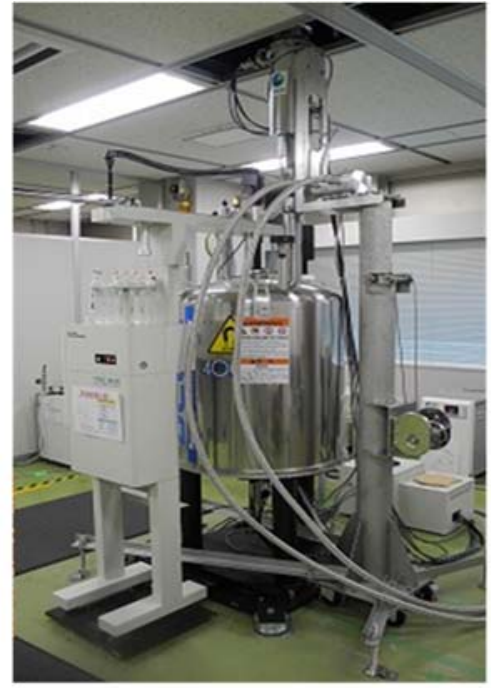

a) A photograph of a recondensation unit for NMR

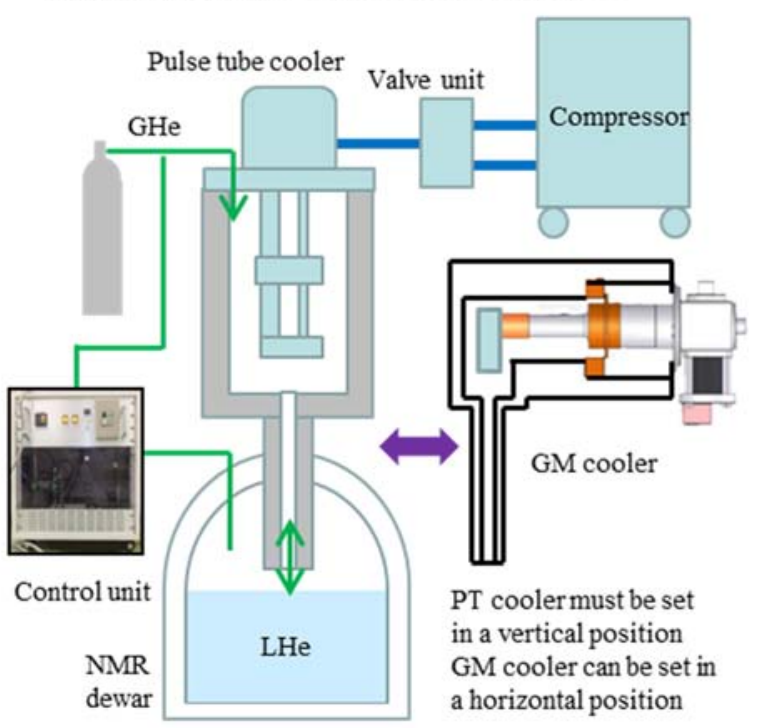

b) Schematic drawings of the system Courtesy of Taiyo Nippon Sanso Co.

Fig. 9 Helium recondensation unit for NMR.

装置全高が高くなる。このため, 当装置の設置には実験室 に十分な天井高さが必要になる。一方, GM 冷凍機は横置 き姿勢で装着できるので，天井の低い実験室では有効であ る。

ここで, 小型冷凍機搭載のヘリウム液化機/再凝縮器選択 の一助になると考え, GM 冷凍機とパルスチューブ冷凍機 の長短を簡単に述べておく。

$\bigcirc \mathrm{GM}$ 冷凍機

・長年の実績と信頼性が高い

- 比較的安価

・冷凍機効率が良い

・取付姿勢の制限が無い

・振動が大きい

・蓄冷材（磁性材料）が往復動する

・磁場中での作動が不安定 
・ヘリウム液化効率が少々劣る

○パルスチューブ冷凍機

・比較的高価

・冷凍機効率が少々劣る

・取付姿勢が直立のみ

・振動が小さい

・磁場による冷凍機運転への影響が小さい

・ヘリウム液化効率が良い

\section{4. おわりに}

今後は世界中で慢性的なへリウム不足が懸念されており, 特に液体ヘリウムの小ロユーザーにとって，液体へリウム の入手が困難になることは予想に難くない。このため, 貴 重な資源であるへリウムは，回収・再利用しなければなら ないが，小型冷凍機を搭載したヘリウム液化機/再凝縮装置 は，有効な実施手段の一つである。恐らく小ロユーザーに は近い将来必要不可欠な機器となるであろう。

このような観点から，GM 冷凍機とパルスチューブ冷凍 機を搭載したへリウム液化機/再凝縮装置について，その進 化と商品化の状況を俯瞰してきた。そこで，以下に小型冷 凍機を搭載したへリウム液化機/再凝縮装置を総括する。

・小型冷凍機を搭載したへリウム液化機/再凝縮器は点在す る少量液体へリウム消費者にとって，ヘリウム資源再利 用の有効な手段である。

・GM 冷凍機とパルスチューブ冷凍機を搭載したヘリウム 液化機の両者の性能には顕著な差は無い。どちらかの選 択は利用者の状況による。

・ 1 台の小型冷凍機でもその液化能力は 20 リッター/日以上 を持っている。

・種々のヘリウム液化機/再凝縮装置が既に世界中で市販さ れ，稼働している。

本解説文を執筆するに当たり，貴重な資料をご提供いた だいた日本カンタムデザイン株式会社坂本氏，住友重機械 工業株式会社福島氏，及び大陽日酸株式会社梅野氏，山中 氏に謝意を申し上げる。

\section{参 考 文 献}

1)「ヘリウム危機」に臨んでの緊急声明文, 日本物理学会ホー ムページ，

https://www.jps.or.jp/information/docs/seimei20191220.pdf（参照 2020-09-04)

2）住友重機械社製 4K-GM-JT 冷凍機カタログ, http://www.shicryogenics.com/wpcontent/uploads/2012/11/4K_GM-JT_Outline_Drawing.pdf（参照 2020-09-04)
3) S. Yoshida, T. Sano, Y. Kamioka, S. Kotani, A. Inoue, H. Suzuki and S. Hasuo: “A cryogenic system for Josephson computers," Advances in Cryogenic Engineering 37 (1992) 623-629

4) S. Yoshida, T. Umeno and Y. Kamioka: "Development of a flexible separated $4 \mathrm{~K}$ head refrigerator for a SQUID system," Advances in Cryogenic Engineering 39 (1994) 1263-1270

5) M. Nagao, T. Inaguchi, H. Yoshimura, T. Yamada and M. Iwamoto: "Helium liquefaction by a Gifford-McMahon cycle cryocooler," Advances in Cryogenic Engineering 35 (1990) 1251-1260

6) M. Sahashi, Y. Tokai, T. Kuriyama, H. Nakagome, R. Li, M. Ogawa and T. Hashimoto: "New magnetic material $\mathrm{R}_{3} \mathrm{~T}$ system with extremely large heat capacities used as heat regenerators," Advances in Cryogenic Engineering 35 (1990) 1175-1182

7) T. Kuriyama, M. Sahashi, H. Nakagome, T. Eda, H. Seshake and T. Hashimoto: "Helium liquefaction by a two-stage GiffordMcMahon-cycle refrigerator using new regenerator material of $\mathrm{Er}_{3}$ Ni,” Jpn. J. Appl. Phys. 31 (1992) L1206-L1208

8) Y. Matsubara and J.L. Gao: "Novel configuration of three-stage pulse tube refrigerator for temperatures below $4 \mathrm{~K}$," Cryogenics 34 (1994) 259-262

9) C. Wang, G. Thummes and C. Heiden: "A two-stage pulse tube cooler operationg below 4 K," Cryogenics 37 (1997) 159-164

10) G. Thummes, C. Wang and C. Heiden: "Small scale ${ }^{4}$ He liquefaction using a two-stage 4 K pulse tube cooler," Cryogenics 38 (1998) 337 342

11) C. Wang: "Efficient helium recondensing using a $4 \mathrm{~K}$ pulse tube," Cryogenics 45 (2006) 719-724

12) Cryomech 社冷凍機カタログ, https://www.cryomech.com/products/pt410/（参照 2020-09-09）

13) P. Schmidt-Wellenburg and O. Zimmer: "Helium liquefaction with a commercial 4 K Gifford-McMahon cryocooler," Cryogenics 46 (2006) 799-803

14) A. Choudhury and S. Sahu: "Experimental helium liquefier with GM cryocooler," Review of Scientific Instruments 88 (2017) 065116

15) Cryomech 社冷凍機カタログ, https://www.cryomech.com/products/pt420/（参照 2020-09-09）

16) Cryomech 社冷凍機カタログ, https:/www.cryomech.com/products/lhep80/（参照 2020-09-09）

17) Quantum Technology 社冷凍機カタログ, https://quantumtechnology.com/documents/COLD\%20HEAD\%20BROCHURES/ QCH4KDHH.pdf（参照 2020-09-09）

18) Quantum Technology 社冷凍機カタログ, https://quantumtechnology.com/documents/LIQUEFIER\%20BROCHURE/QLHe2 0-40-60-80-100-200Lday.pdf（参照 2020-09-09）

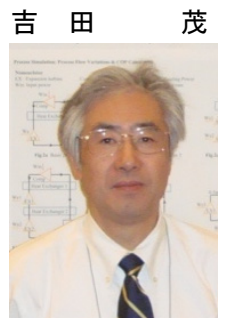

1957 年 1 月 30 日生。1980 年早稲田大学理工 学部機械工学科卒業。2003 年九州大学大学院 博士後期課程（エネルギー量子工学専攻）修 了。1982 年東洋酸素 (株) (現大陽日酸 (株)) 入社。2018 年九州大学教授。主に低温機器開 発に従事。低温工学・超電導学会, 電気学会 会員。工学博士。 